tween its electrodes, and thus in theory it should be possible to make an absolute standard of capacitance against which all other capacitors can be compared. However, absolute standards of inductance can be designed and constructed with considerably greater accuracy, and measurements of capacitance are ultimately based, in conjunction with a frequency standard, on the Campbell standard of mutual inductance which is the absolute standard of reactance at the Laboratory.

\section{Catalogue of Nuclear Reactors}

THE Chalk River Project of Atomic Energy of Canada, Ltd., with the co-operation of the Atomic Energy Research Establishment, Harwell, has prepared a "Catalogue of Nuclear Reactors 1955" (AECL No. 220; CRR-590. Pp. 60. London : H.M.S.O., $1955 ; 4 s .6 d$. net), which has been compiled from the unclassified literature and refers to reactors that are known to have reached criticality by July 1955. The catalogue includes reactors in Canada, France, Great Britain (BEPO, DIMPLE, GLEEP and ZEPHYR at Harwell and the two reactors at Windscale), Norway, Sweden, Switzerland, the United States (about forty reactors, including six at Areo, Idaho, and nine at Hanford, Washington) and the U.S.S.R. The details given for each reactor consist of brief notes covering six items -neutron speed; fuel configuration; kind of moderator ; purpose (research, power, etc.) ; thermal power ; and neutron flux-as well as constructional details and one or two useful references. Additions to, and revisions of, the catalogue will be prepared from time to time in order to keep the collection of data up to date.

\section{Chemistry Films}

A sPECIAL issue of the Scientific Film Review catalogues films on chemistry and allied topics (2, No. 2; June 1956). The list is derived from one compiled by the Scientific Film Association in 1949 and includes the appraisals then prepared by the Association's viewing committee. To the appraisals have been added films from many recent catalogues, one or two reviews and some foreign films. For the catalogue, chemistry has been widely interpreted so that no known film likely to be of use has been omitted. Among the sections for which films are included are agriculture, atomic physics, crystallography, laboratory techniques, industrial manufacturing processes, microscopy and public health.

\section{International Abstracts of Biological Sciences}

THE Council of Biological and Medical Abstracts, Ltd., has decided to change the title of its journal British Abstracts of Medical Sciences to International Abstracts of Biological Sciences. This decision has been brought about, first, by an extension of the scope of the Abstracts to a wider range of biological research subjects published in journals throughout the world, and, second, by the fact that the International Abstracts of Biological Sciences, with the co-operation of the specialist editors selected by the Institute of Scientific Information of the Academy of Sciences of the U.S.S.R., will include, as from the January 1957 issue, translations of important Russian papers abstracted in the Referativny Zhurnal Biologii (Soviet biological abstracts) and Referativny Zhurnal Biologischekoi Khimii (Soviet abstracts of biological chemistry), to be published simultaneously with their appearance in Russian. The Abstracts are published for the Council of Biological and Medical Abstracts, Ltd., by the Pergamon Press, of London and New York, on a non-profit-making basis, and the honorary editor is Dr. C. C. N. Vass. Since the Russian abstracts will have to be translated, the Council requires translators with knowledge of anatomy, animal behaviour, biochemistry, endocrinology, experimental biology, experimental medicine, microbiology, odontology, pathology, pharmacology and physiology, and would welcome offers of help. Terms of payment and other details can be obtained from Dr. C. C. N. Vass, c/o Pergamon Press, Ltd., 4-5 Fitzroy Square, London, W.1, or 122 East 55 th Street, New York 22, N.Y.

\section{Political and Eccnomic Planning}

IN Broadsheet No. 400, entitled "PEP 1931-56" (Planning, 22, 141; July 23, 1956; 2s. 6d.), Political and Economic Planning explains its purpose and methods of working, emphasizing particularly the dependence of its success on the anonymity of the groups and the insistence on the importance and nature of research in relation to public affairs. For each study it has brought together both experts skilled in various aspects of the subject under study and laymen chosen for their ability to ask the necessary questions and to hold the balance between conflicting specialists whenever necessary. For the most part, $\mathrm{PEP}$ has concentrated on research into the results of available research and into material and experience already gathered for other purposes, except where first-hand sample investigations have been essential. For the past two years, PEP has been engaged on two projects financed under the Conditional Aid Scheme for the Use of Counterpart Funds derived from United States economic aid. A report on the first, which will provide accounts of the work of particular trade associations and their relation with individual firms and public corporations, is due for publication later this year. The second consists of a survey of the employment entered by men graduating in a selected year, 1950, which is also to be published this autumn under the title "Graduate Employment", and a survey of the policy and practice of industrial undertakings in employing graduates. PEP is also engaged on two other major studies: one, expected to take three years, on adaptation in industry; and the other on family needs and the social services. The present broadsheet suggests that the fundamental strength of Political and Economic Planning is in its intellectual initiative and possession of the necessary qualities and resources to continue pioneering new fields and new techniques; but the report emphasizes the need for regular ineome and for more subsidies if the volume and quality of the work are to be maintained.

\section{Training for Supervisors}

"IF we are going to be really efrective in world competition, then we must make for greater efficiency and one of the ways of doing so is by having better supervision." These are among the concluding words of a discussion between five people from different spheres of industrial life recorded in a booklet called "Training for Supervisors" which has been issued by the Ministry of Labour and National Service. The five people-a training officer, general manager, director, production superintendent and shop foreman-met to express their views on the conclusions of the 1954 Report of the Committee 